\begin{tabular}{|l|l|l|l|}
\hline Rudarsko-geološko-naftni zbornik & Vol. 7 & str. 77-85 & Zagreb, 1995. \\
\hline
\end{tabular}

\title{
TRAVERTINE THE RESTORATION STONE FOR THE ZAGREB CATHEDRAL
}

\author{
Branko CRNKOVIĆ ${ }^{1)}$ and Francesco POGGI ${ }^{2)}$ \\ 1) Faculty of Mining, Geology, and Petroleum Engincering, Pierottijeva 6, RH-10000 Zagreb, Croatia \\ 2) Bruno Poggi \& Figli, Industria Travertino Romano, P.O.Box-00011 Bagni di Tivoli, Italy
}

Key-words: Travertine, Deposit, Genesis, Properties, Calc-tufa

Roman travertine San Pietro Classico, from a deposit in the Acque Albule basin near Rome, will be used for the restoration of the cathedral in Zagreb instead of the previosly used lithotamnian limestone.

The genesis and properties of travertine are described. Also the differences in genesis and characteristics of travertine and calc-tufa are presented. Travertine and calc-tufa are created by different genetic processes and thus cannot be considered equivalent. Travertine is a dimensional stone that has world-wide significance, while calc-tufa, has only local or at the most some minor regional importance.

\section{Introduction}

In the past lithotaminian limestone was the construction stone of Zagreb. It was excavated on the south-west slopes of Mt. Medvednica, and was used to construct many buildings, including the Zagreb cathedral.

Lithotamnian limestone is unstable in a polluted urban environment, especially under the influence of acid rain that contains carbonate and sulfate anions. This influence is particularly significant upon siltoze lithotamnian limestone whose surface is covered with thinner and/or thicker crusts and scabs that contain notable amounts of gypsum (C r n k o v i ć et al., 1994). Analyses results of built in lithotamnian limestone showed "contamination" with calcium-sulfate to the depth of $18 \mathrm{~cm}$. Because of the large damages of the built in limestone, the replacement of the entire stone gallery began. Roman travertine was selected as a substitute, since it is similar to the lithotamnian limestone in color, porous structure and dressed surface appearance.

In Zagreb, roman travertine was used for the first time about some 70 years ago. It was found to be suitable and durable in the urban environment. Since it has been recommend that all the damaged lithotamnian limestone built into Zagreb buildings, be replaced during building restorations by travertine, we consider it appropriate to present basic information on the deposits, genesis and characteristics of this stone. Also the basic differences in origin needed to distinguish between travertine and calc-tufa (calcareous tufa) are presented.

\section{The travertine deposit in the Acque Albule basin}

The use of travertine as a building stone, and as a constructive and decorative element, dates back to ancient times. Travertine in ancient buildings has
Ključne riječi: Travertin, Ležište, Geneza, Svojstva, Calc-tufa (sedra)

Za obnovu zagrebačke katedrale umjesto dosada ugrađenog litotamnijskog vapnenca ugrađuje se rimski travertin San Pietro classico iz ležišta u bazenu Acque Albule nedaleko Rima.

Opisani su geneza i svojstva travertina. Izložene su razlike u genezi i svojstvima travertina i sedre. Travertin i sedra su tvorevine različitih genetskih procesa $i$ ne mogu se međusobno poistovjećivati. Travertin je arhitektonski kamen od svjetskog značenja, a sedra od lokalnog, eventualno regionalnog.

withstood the test of time. Vitruvius (active 46-30 BC), a famous Roman architect, wrote about travertine: "Le pietre tiburtine, e quelle che sono della stessa specie resistono a tutto, si al peso, si ancora alle ingiurie del tempo, ma non sono sicure dal fuoco ..." (after P i e r i, 1950).

C o r s i (1828) considered travertine, that covers a large surface area of the Acque Albule basin, to be a river sediment. He wrote: "Il marmo tiburtino volgarmente detto travertino è composto di sostanca dalle acque del fiume Aniene".

The travertine deposit in the basin of Acque Albule was geologically described in detail by $\mathrm{M} \mathrm{a} \mathrm{x} \mathrm{i} \mathrm{a} \mathrm{(1950a,}$ $1950 \mathrm{~b})$, and he also published a geological sketch of the basin (Fig. 1).

The basin is of oval shape. The longer axis, in the ENE-WSW direction is about $9 \mathrm{~km}$ long, and the shorter one, in the NW-SE direction, is about $7 \mathrm{~km}$ long. The basin area spans about 45 square $\mathrm{km}$. It generally descends from the north to the south, from $81 \mathrm{~m}$ at Guidoni to $50 \mathrm{~m}$ on the river Aniene, and from east to west, from $75 \mathrm{~m}$ at Acquoria to $30 \mathrm{~m}$ at Lunghezzino. It is outlined with the Tiburtini and Lucretili mountains on the east, the Cornicolani mountain on the north, the Tevere basin lay to the west, and the Laziale volcano lays to the south.

The listed mountains consist of marls, marlaceous and siliceous limestones of Creataceous and Jurassic age, and massive limestones of Liassic interior. The Mesozoic limestones are karstified and create a water drainage zone. The waters of these karst regions are collected and supply the basin subterraneously.

Clastic sedimentary rocks with Pliocene marine fossils and alluvial sand-clay terraces lay over the Mesozoic carbonate rocks.

The important member in the base of travertine is the pyroclastic-volcanic complex that, from the basis up, consists of gray leucitic tuff, leucitite, lithic tuff and 


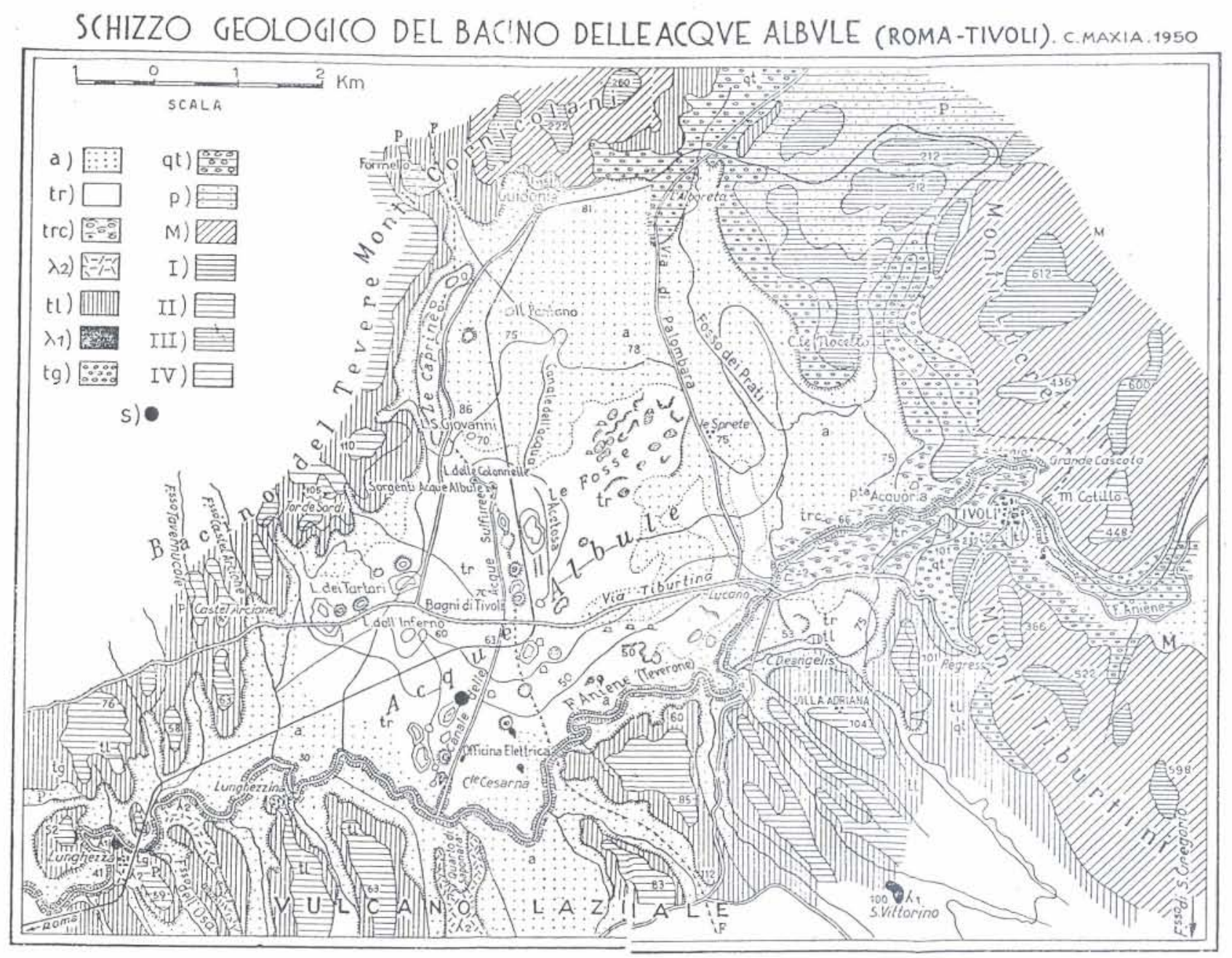

Fig. 1. Geological sketch of Acque Albule basin (after Maxia from C or t e s i \& Le o n i, 1958)

Legend

a Alluvial actual and recent

tr Limestones encrustation and layers, so-called "Tartari" ("Wine-stone")

trc Limestones concretionary, clayey, thin stratified ("Tartari" of Cascata and Tivoli)

tl Complex of leucitic tuff comprises red lithoid tuff for construction ("Tufo litoide rosso da construzione") at the top, and red puzzolan ("Pozzolana rossa") at the base

$\lambda_{2}$ Leucitite of S. Vittorino and Lunghezza

tg Grey leucititic tuff of "granular" appearance sometimes by white pumice (appertains to complex of "Tufi antichi")

qt Alluvial terraces sandy-clayey

p Yellow sand and conglomerates with marine fossils (partially Calabrian)

M Marls, limestones marlaceous and siliceous of Cretaceous and Jurassic. Massive limestones of Liassic Interior

I Terraces from 600 to $500 \mathrm{~m}$ limestones of Mesozoic

II Terraces from 450 to $350 \mathrm{~m}$ limestones of Mesozoic

III Terraces from 250 to $180 \mathrm{~m}$, limestones of Mesozoic and sediments of Pliocene

IV Flat surfaces from 120 to $60 \mathrm{~m}$, clastic sediments of Plio- Pleistocene and pyroclastic rocks

S Borehole (Bagni di Tivoli)

thin-bedded limestone. The pyroclastic-volcanic complex is the base for travertine strata which are partly covered by recent alluvial sediments.

There are four terraces designated on the geological sketch. The first terrace, which spans from $600 \mathrm{~m}$ to $500 \mathrm{~m}$, and the second terrace, traversing from $450 \mathrm{~m}$ to $350 \mathrm{~m}$, consist of Mesozoic limestones. The third terrace (from $250 \mathrm{~m}$ to $180 \mathrm{~m}$ ) is comprised of Mesozoic limestones and Pliocene sedimentary rocks, and the fourth terrace (from $120 \mathrm{~m}$ to $60 \mathrm{~m}$ ) consists of sediments of Plio-Pleisticene sedimentary rocks and pyroclastic rocks.

The general fault zone and the main thermal flow zone extent in the SSE direction (Fig. 1, F-F), from Formelo, north of the basin to the east of the Laziale volcano. Along this zone, according to $\mathrm{M}$ a $\mathrm{x}$ i a (1950b), juvenile and vadose water from mentioned karst regions occur are mixing.

At the site Bagni di Tivoli, about $1 \mathrm{~km}$ SSW from Bagnio and $50 \mathrm{~m}$ west from the Acque Sulfuree canal, 
on the elevation $48 \mathrm{~m}$, in the region with widespread travertine outcrops, an exploration well was drilled in 1948. A total length of $85 \mathrm{~m}$ of travertine core was obtained and the well ended in travertine.

Along the travertine core profile, M a x i a (1950a) separated the following varieties:

- "Tartari" and "Cardelline" ("winestone" and "goldfinch") (6 m)

The notion of "Tartari" in the region of Acque Albule means limestone incrustrations of intertwined plants, especially stems and leaves. On the other hand, the notion "Cardelline" indicates travertine that is porous and light, with variable amount of impurities.

- Travertine, white-yellowish (23 m)

- Travertine, gray, compact, with freshwater mollusks $(1.3 \mathrm{~m})$

- "Tartari", oolitic travertine, clay travertine, banks of white compact travertine in alternation with layers of travertine with plants, freshwater mollusks and soil $(43.7 \mathrm{~m})$

- Travertine, gray brecciated, (1.6 m)

- Travertine, white, compact and cavernous (9.4 m).

Among the fossil remnants in travertine, $\mathrm{M}$ a x i a (1950b) mentions numerous terrestrial vertebrates and invertebrates.

Corte s i and Le o n i (1958) carried out detailed granulometric, mineralogical and chemical analysis of 18 samples of travertine core, and 23 samples of the surrounding Mesozoic, Paleogene and Pliocene rocks.

The dissolution of travertine samples of in cold $2 \%$ hydrochloric acid, gave the soluble portion travertine (from 84.33 to $99.99 \%$ ) and unsoluble residue that was fractionated as sand $(0.02$ to 2.00 $\mathrm{mm})$, silt $(0.002$ to $0.02 \mathrm{~mm})$ and clay ( $<0.002 \mathrm{~mm})$.

The sand fraction of the insoluble residue in travertine varied from 0.002 to $8.0 \%$, the silt fraction from 0.002 to $2.35 \%$ and clay fraction from 0.000 to $5.32 \%$.

The principal constituents of the sand fraction in the insoluble residue of travertine with density less then $2.8 \mathrm{~g} / \mathrm{cm}^{3}$, is quartz $(34.8-73.3 \%)$, chalcedony $(0.00-25.2 \%)$ and sanidine (3.1-44.6\%). Quartz and sanidine were determined in all analyzed unsoluble travertine residuals. In the rest of the samples, sponge (porifera) spicules and radiolaria were determined (in 12 samples, up to $3.3 \%$ ), and volcanic glass and pumicite (in 6 samples, up to $39.0 \%$ ), lava and tuff (in 4 samples, up to $18.3 \%$ ), coal particles (in 8 samples, up to $31.1 \%$ ), mica and chlorite (in 9 samples, up to $35.7 \%$ ), microcline (in 2 samples) and zeolite (in 1 sample). In the fraction with density $>2.8$ $\mathrm{g} / \mathrm{cm}^{3}$, pyroxene, garnet, magnetite, pyrite-marcasite, ferro oxide, barite, olivine, hornblende, glaucophane, realgar, titanite, epidote, turmaline, rutile, micas and chlorite were determined.

The samples of Mesozoic, Paleogene and Pliocene rocks were analyzed in the same fashion.
Comparing the composition of the sand fractions of insoluble travertine residue and the surrounding rocks it is obvious that sanidine, microcline, volcanic glass and pumicite, lava and tuff, zeolite, barite, olivine, realgar and titanite are found only in the analyzed samples of travertine, and while pyrite-marcasite, apart from the travertine samples, was also found in the Liassic limestone. The conclusion of the author is that the main part of the insoluble travertine residue components is of volcanic origin.

In silt fraction of the insoluble travertine residue, quartz and muscovite were determined by X-ray powder diffraction analysis.

In clay fraction of the insoluble travertine residue, determined by X-ray powder diffraction analysis was quartz, hydromicas, the chlorite-group minerals and the kaolinite-group minerals.

In the soluble fraction of travertine samples, the amount of $\mathrm{CaCO}_{3}$ varied from 81.50 to $98.83 \%$, the portion of $\mathrm{CaSO}_{4}$ from 0.81 to $2.38 \%, \mathrm{MgCO}_{3}$ from 0.15 to $1.30 \%$ and the portion of $\mathrm{SrCO}_{3}$ from 0.10 to $0.30 \%$.

The difference between the ratio of $\% \mathrm{Sr} / \mathrm{Ca} \times 10^{3}$ in Mesozoic and Paleogene carbonate rocks (from 0.26 to 1.96 ) and travertine (from 1.58 to 4.82 ) is also indicative.

The second author has presented the basic data for the deposit at the National Meeting for TRAVERTINO ROMANO IN TIVOLI held in 1984 in the short account "Cenno geologico sulla formazione del complesso travertinifero nel bacino delle Acque Albule". He expounded the definition, the sedimentation processes and the precipitation of $\mathrm{CaCO}_{3}$, the presence of vegetation, the sedimentation cycles, density and color.

The exploitability of travertine was given by $\mathrm{M}$ a $\mathrm{x}$ i a (1950b), describing the exploitable layers:
- Cappellacio tartaroso
(wine-stone hat) thickness
- Travertine banks
$1.5 \mathrm{~m}$
- Brown soil layer
25.0
- Travertine banks
1.0
14.0

a total of $\quad 41.5 \mathrm{~m}$

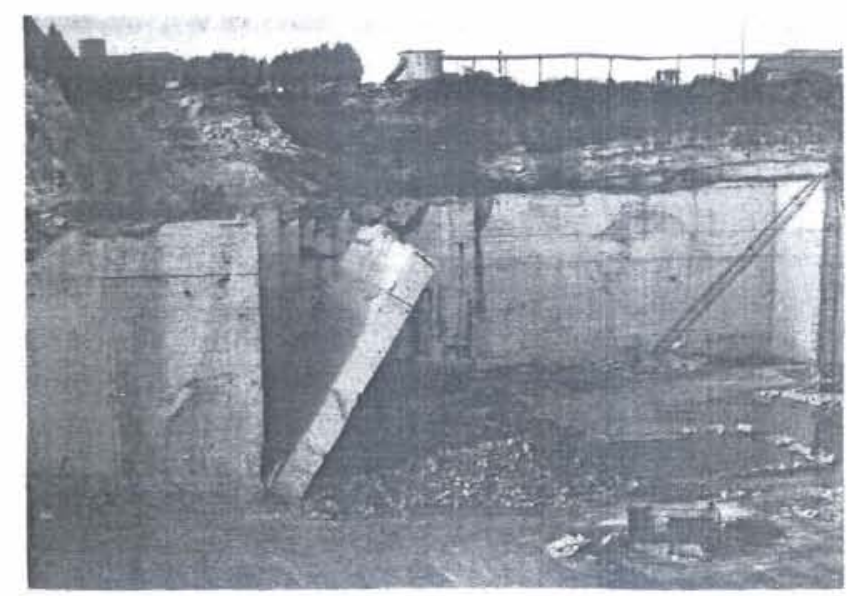

Fig. 2. Bruno Poggi \& Figli Travertine plain quarry (open-pit type) 
The exploitable layers of travertine occur close to the surface, with only a thin overburden (Fig. 2). Genesis

Definition of travertine as sedimentary rock formed by precipitation of $\mathrm{CaCO}_{3}$ from waters saturated with $\mathrm{Ca}\left(\mathrm{HCO}_{3}\right)_{2}$ is not unequivocal without taking into account the origin of these waters. That is probable cause that travertine is considered to be equivalent with calc-tufa in many dictionaries and encyclopedias.

Let us cite only several examples.

(1) Editors B a t e s and J a c k s o n (1980) write: "(a) A dense, finely crystalline massive or concretionary limestone, of white, tan, or cream color, often having a fibrous or concretric structure and splintery fracture, formed by rapid chemical precipitation of calcium carbonate from solution in surface and ground waters, as by agitation of stream water or by evaporation around the mouth or in the conduit of a spring, esp. a hot spring. It also occurs in limestone caves, where it forms stalactites, stalagmites, and other deposits, and as a vein filling, along faults, and in soil crusts. The spongy or less compact variety is tufa. (b) A term sometimes applied to any cave deposit of calcium carbonate."

(2) T o m k e i e f f (1983) writes: "Travertine, a variety of calcareous tufa which is generally of light colour and may be dense and compact or porous. It is often in irregular layers which ramify through cavities and may in part be biochemical in origin. It forms where lime-bearing waters are agitated, as along the base of streams, around hot springs, along faults, etc.

Travertine deposits may be considerable extent where they cover the beds of former lakes and are generally valued as an ornamental stone, or, where massive, as buildings blocks."

(3) Editors A Il a b y, A and A Il a b y, M. (1990) write:

"Calcium carbonate deposited by precipitation from carbonatesaturated waters, perticularly from hot springs. Travertine deposits are sometimes massive, but often display a concentric or fibrous internal structure, sometimes building large, concentric, spherical masses. Travertine is also found in cave deposits in the form of stalactites and stalagmites. A porous, sponge-textured form of travertine is reffered to as tufa or calc-sinter:"

(4) W a g n e r (1994) writes: "Travertine ... is a dense, closely compacted form of limestone ... It forms when calcium carbonate separates from water through evaporation ... It often forms around the mouths of hot springs and streams ... Rock formation called stalactites and stalagmites which are found in caves, consist primarily of travertine." (!?)

There are exceptions, as M e h $\mathrm{l}$ in $\mathrm{g}$ (1986) whose descriptions depart from said analogy of travertine and calc-tufa, and writes: "Travertin poröses Kalkstein, das sich in den jüngeren Epochen kontinental immer dann bildete, wenn kalkreiche Wässer mit salzoder säuerhaltigem Wasser (Mineralquellen) versetz werden ... Häufig im Zusammenhang mit Vulkanismus stehend ... Kalktuff, locker oder poröser Gestein aus Karbonaten ... fast immer im Süsswasser unter Mitwirkung von Algen abgelagert ... Als Baustein regional beliebt."

Published definitions of travertine in newer editions did not take into account new genetical ideas about terrestrial limestones such as travertine, calc-tufa and speleothems (Fl ü g e 1, 1982, T i § l j a r, 1994).

The common feature of both terrestrial limestones, travertine and calc-tufa, is precipitation from water saturated with calcium hydrocarbonate. The difference between them is in origin of these waters. Travertine is formed by deposition from warm juvenile water genetically conected to areas of volcanic activity, or by precipitation from deep warm mineralized waters, or by mixing of these waters with meteoric waters before they spring at the surface. Calc-tufa is formed by precipitation from cold waters, and genetically it is, like speleothems, in close connection with chemical processes and phenomenology of karst. These waters differ in their origin and composition.

The gas chemistry of geothermal systems was described by A r n ó r s s o n (1990). Generally over $99 \%$ of total gas is composed of $\mathrm{CO}_{2}, \mathrm{H}_{2} \mathrm{~S}, \mathrm{H}_{2}, \mathrm{CH}_{4}$ (and other hydrocarbons), $\mathrm{N}_{2}$ and $\mathrm{NH}_{4}$. These gases are reactive chemically, they react with the rock, between themselves or with aqueous solutes. Warm to hot waters rich in $\mathrm{CO}_{2}$ are very widespread in the world. The distribution of $\mathrm{CO}_{2}$ waters with major zones of historical seismicity is generally striking. On a global scale $\mathrm{CO}_{2}$ discharges occur largely in the same zone as active volcanism and high-temperature geothermal systems. $\mathrm{CO}_{2}$-rich waters are probably produced for the most part by active metamorphism where $\mathrm{CO}_{2}$ is released as a result of reactions between carbonates and silicates.

Both sediments are a result of the equilibrium state of the basic reaction ( $\mathrm{K}$ r a u s k o p f, 1982):

$$
\begin{gathered}
\mathrm{H}_{2} \mathrm{O}+\mathrm{CO}_{2} \\
\mathrm{CaCO}_{3}+\mathrm{H}_{2} \mathrm{CO}_{3} \Leftrightarrow \mathrm{Ca}^{2+}+2 \mathrm{HCO}_{3}^{-}
\end{gathered}
$$

valid in complex conditions, with variations in concentration, temperature, pressure, organic activity, presence of natural buffers, contents of electrolyte and so on.

Recent development of a small travertine precipitating system in SW Colorado north of Durango was described by $\mathrm{Ch}$ a f e $\mathrm{t} z$ et al. (1991). The authors explicitly say in the introduction: "Travertine precipitation occurs from spring waters that display a wide range of natural conditions, e.g. from those with ambient temperature ... to essentially boiling water ... from waters with slightly elevated pCO2 $\ldots$ to those highly charged with dissolved $\mathrm{CO}_{2} \ldots$ from waters slightly supersaturated with respect to $\mathrm{CaCO}_{3} \ldots$ to those that are extremely supersaturated with respect to $\mathrm{CaCO}_{3}$."

After general field description of the natural springs in the hillside they presented water chemistry data. The measured water temperature from $23^{\circ}$ to $36^{\circ} \mathrm{C}$, ranged as a function of distance from the vents and solar heating. The $\mathrm{pH}$ of the waters at the springs ranged from 6.1 to 6.35 , and rose rapidly at the surface as a result of $\mathrm{CO}_{2}$ degassing, but rapidly increased in the downflow direction from an average value of 6.8 ( $2-3 \mathrm{~m}$ from spring) to 7.2 (about $25 \mathrm{~m}$ downflow), and as high at 8.0 (at the base of mound). The partial pressure of $\mathrm{CO}_{2}$ ranged from $1.2 \times 10^{5} \mathrm{~Pa}$ at the vents to $8.2 \times 10^{2} \mathrm{~Pa}$ at the base of mound. Saturation index (ISAT) values display a similar trend. The spring waters emerged at the surface slightly supersaturated with respect to calcite (ISAT $=2.1$ - 
3.9). Within $25 \mathrm{~m}$ in the downflow direction the waters became moderately supersaturated (ISAT $=$ 9.98). On the top part of the mound waters are extremely supersaturated (average ISAT $=48$ ). Oxygen and carbon isotope data are also presented. The solid phases precipitated from the water are all isotopically heavier, because the lighter carbon is selectively lost to system by degassing.

Precipitates of calcium carbonate near the springs and the mound are also described. The initial precipitation of $\mathrm{CaCO}_{3}$ that occurred in the water near the springs consists of floating rafts of carbonate. Encrusted filamentous algae were also encountered. Calcite is the only phase of $\mathrm{CaCO}_{3}$. The surface of the travertine mound consisted entirely of a sponge-like accumulation of calcite and aragonite, and some plant detritus. Carbonate-encrusted bubbles and floating rafts were collected from the surface of the travertine mound.

Carbonate-encrusted bubbles are hollow, spherical accumulations of calcite and aragonite, generally a few millimeters in diameter. The bubbles, the product of photosynthetic activity of micro-organisms, are initially composed of oxygen, and are devoid of $\mathrm{CO}_{2}$. The bubbles can also be the product of $\mathrm{CO}_{2}$ release, from $\mathrm{Ca}\left(\mathrm{HCO}_{3}\right)_{2}$, when $\mathrm{CaCO}_{3}$ is precipitated and $\mathrm{CO}_{2}$ released in the folloving reaction:
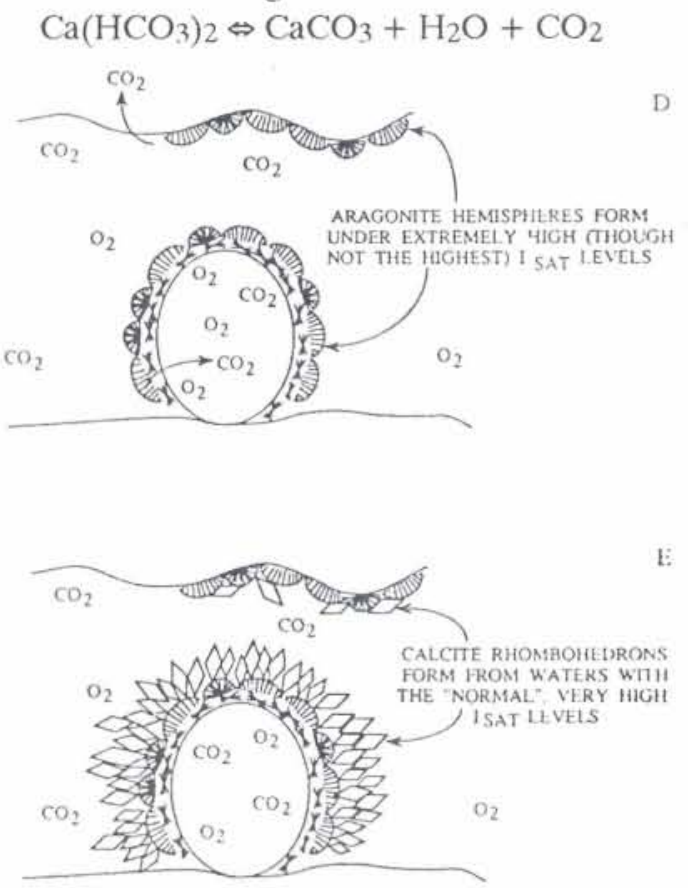

Fig. 3. Shematic depiction of the origin of the carbonate- encrusted bubbles and floating rafts (from $\mathrm{C} h$ a f e $\mathrm{t} z$ et al. 1991)

D - Hemispheres of aragonite form around the stellate clusters of aragonite and also form floating rafts at the water-air interface due to elevated Isat

E- The final phase of carbonate-encrusted bubble formation consist of the precipitation of rhomboedra of calcite on their surface; this is analogous to the precipitation of rhomboedra of calcite on other available surfaces, e.g. vegetable matter
Thin diaphanous rafts of $\mathrm{CaCO}_{3}$ floated on the surfaces of the shallow pools that had occurred behind the innumerable rimstone dams that covered the surface of the travertine mound. These rafts are composed of a layer of laterally linked hemispheres of radiating aragonite needles (Fig. 3).

In the basin Acque Albule travertine deposit, in some parts we find the structures just described, such as bubble-like formations (Fig.4), and raft shaped accumulations which are shattered, partly immersed, so that the travertine has breccia like features (Fig.5).

A favorable condition is that, besides calcite, aragonite also precipitates, and later transforms into calcite. The transformation is followed by increase in

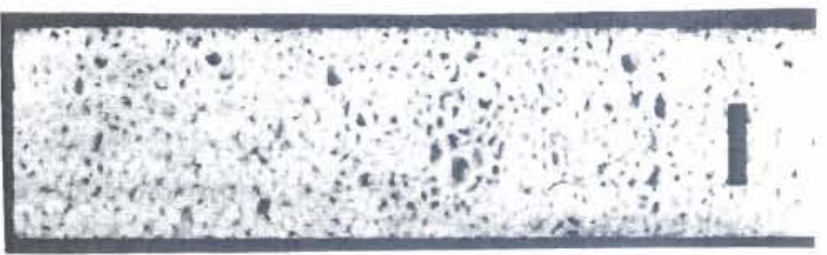

Fig. Sample of Roman travertine with vuggy structure and carbonate-encrusted bubbles. Cut parallel to bedding (mark = $1 \mathrm{~cm})$

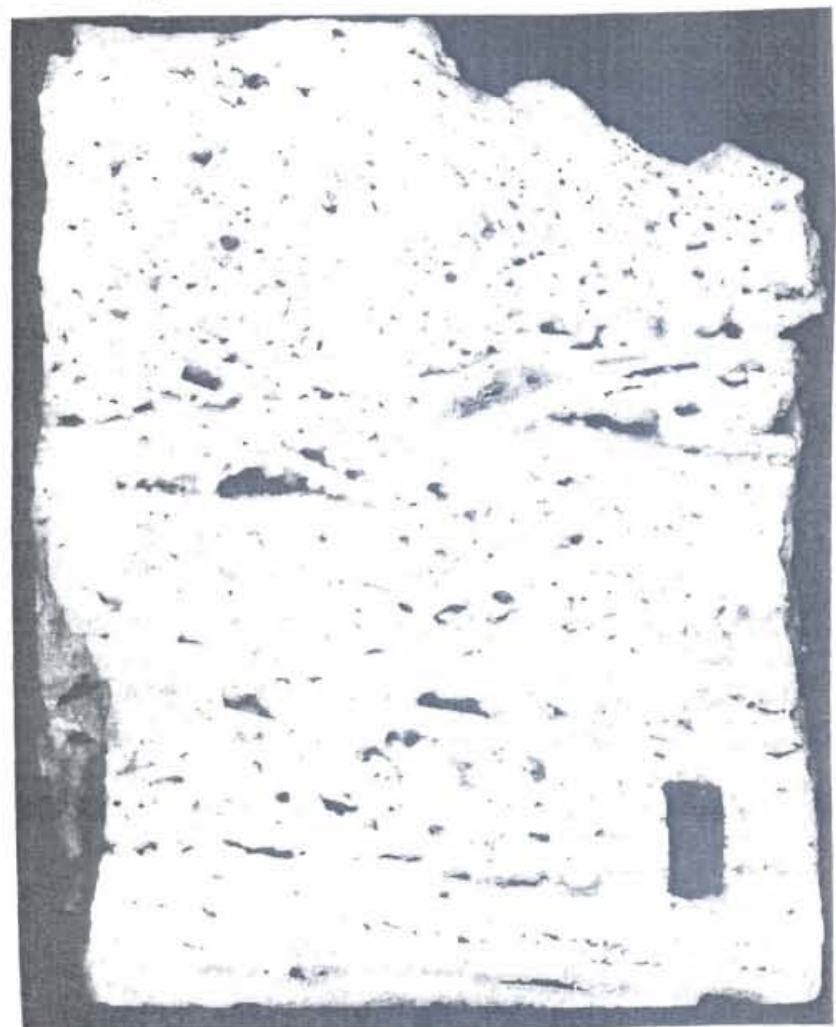

Fig. 5. Sample of Roman travertine with broken flat floating rafts and breciatted appearance. Cut perpendicular to bedding $($ mark $=1 \mathrm{~cm})$

the volume of newly formed calcite in the crystal aggregate, causing the aggregate to become more dense, and therefore more compact. Microscopic investigations of travertine determined that changes 
in volume are not of such extent to induce formation of crystalo-deffects (undulose extinction, grain fracturing, segmentation, biaxiality and pressure twining lamellae) in the calcite that was precipitated and in the one formed by aragonite transformation.

Aforesaid complex conditions of $\mathrm{CaCO}_{3}$ precipitation together with presented data, conditioned the forming of different structural and textural varieties of travertine, with accentuate stratification and sometimes with obvious interruptions of sedimentation. The abundance of varieties is also enlarged by later recrystalization, crystallization of larger calcite crystals with prominent rhomboedric froms in pore space and caverns, and also by numerous sinsedimentary processes in the unconsolidated sediment.

Current travertinization and the importance of characteristic types of vegetation in forming of the Plitvice Lakes barriers, in a typical karst region, were described by $\mathrm{M}$ a $\mathrm{t}$ o $\mathrm{n}$ i $\check{c k}$ i n et al. (1971). In the process of development, forming and growth of current travertine, living communities have been of great importance. In the currents exposed to light there evolves the photophile moss and the crustacea. In the aerated habitats is the sciofile moss. The basis of communities in the flows that are poorly aerated is the aquatic hepatics. The presence of living communities on the travertine barriers results in the formation of a great vareity of travertine type due to water flow and aeration, like travertine "chins", "curtains", consoles, chanels, conduits, little barriers, caves and semicaves.

The spectacular tufa barriers of the Plitvice Lakes were described by $\mathrm{E} \mathrm{m} \mathrm{e} \mathrm{i} \mathrm{s} \mathrm{et} \mathrm{al.} \mathrm{(1987).} \mathrm{Those}$ barriers were formed by precipitation of $\mathrm{CaCO}_{3}$ from cold water which is saturated with calcium hydrocarbonate in karst regions.

Chemical analysis conducted by Kempe and Emeis and their observations impled that travertine deposition was not solely governed by carbonate supersaturating of river and lake waters. No doubtly it appeared that biological activity of certain macrophytes and epiphytes determined whether or not travertine dams grow.

According to $\mathrm{C} \mathrm{h}$ a f t e $\mathrm{z}$ and F o $1 \mathrm{k}$ (1984), bacterial colonies are the main agents that trigger calcite deposition, and these bacteria are responsible for up to $90 \%$ of the calcite precipitated in certain sulfide-rich hydrothermal travertines. The tufa barriers of the Plitvice Lakes belong to the group termed "cascade deposits" and "shallow lake-fill deposits".

E m e i s et al., (1987) encountered three regimes of carbonate deposition, each creating a typical sedimentary facies:

1 - Euhedral carbonate grains of pure $\mathrm{CaCO}_{3}$ form micritic lake marl mud that covers lake bottoms, with considerable admixture of diatomic frustules in spring/summer layers.
2 -Travertine deposits of the dams can be classified as moss tufa and Oscillatoriacea tufa from cyanobacterial colonies.

3 - Apparently inorganic deposits are rare and restricted to the splash zone of waterfalls, where rapid degassing of $\mathrm{CO}_{2}$ occurs upon impact of water droplets and results in spontaneous precipitation of pure, solid calcite.

The authors conclude that the formation of travertine dams is closely related to biogenic factors. All cascade deposits have a considerable admixture of diatoms in the carbonate matrix. Diatoms play a fundamental role as epiphytes on natural (moss surfaces and wood) and artifical surfaces, together with an unknown contribution from prokaryotes.

If we accept the new conceptions (F l ü g e l, 1982, $\mathrm{T}$ i ̌ $1 \mathrm{j}$ a r, 1994), then we would have to single out the following sedimentary rocks within the terrestrial limestones:

(1) Travertine, formed by precipitation of $\mathrm{CaCO}_{3}$ as calcite and aragonite from warm waters saturated with calcium hydrocarbonate. These waters are:

=juvenile, genetically connected to postvolcanic processes,

$=$ mineralized deep waters, enriched with anions and cations dissolved from rocks located deeper

below the surface under higher temperatures and pressures,

=mixed type, when juvenile or deep waters before surfacing mix with waters of meteoric origin.

(2) Calc-tufa or tufa (in Croatian: sedra), formed by precipitation of $\mathrm{CaCO}_{3}$ as calcite from cold waters saturated with calcium hydrocarbonate, is a sediment distinctive for chemical reactions that occur in karst regions, when in surface waters barriers are formed with the aid of vegetative colonies, or by deposition of micrite calcite mud in rivers or lakes as incrustrations on different detritic materials.

(3) Speleothems (cave formation or dripstone), mineral deposit that is formed in a cave by the action of cool water saturated by calcium hydrocarbonate, including stalactites and stalagmites.

The concept of travertinization, so accentuated by some authors, in our opinion cannot be adopted. Namely, there are no physical or chemical processes that transform calc-tufa into travertine, changing its structure and appearance.

\section{Technical characteristics}

Travertine from the Acque Albule basin is mainly yellow-whitish to yelllow-grayish in color. Some parts are distinctly of a different gray or brown tint.

They are distinctly stratified. The layers are accentuated by subparallel arrangement of cavities, distinct denser parts and changes in color. They are of very heterogeneous structure: ranging from sponge-like appearance, to layers with clearly accentuated bubble-like porosity, and sections with breccia-like appearance. Some distinct layers are clearly slightly 
folded as flexures, as a results folding caused by synsedimentary interlayer sliding in yet unconsolidated sediment beds. A part of the larger cavities, which are mostly parallel with bedding planes, is filled with larger crystals of calcite with distinct tabular rhombohedric habit. Interlayer uconformities of a greater extension along which the main rock body of travertine could be divided, are relatively rare.

Considering the described differences in structure, there are many travertine varieties with different commercial names, like Travertino Romano: chiaro, chiaro fosse, classico, michelangelo, San Pietro classico, San Pietro venato, scuro, oniciato, fidia, adriano, alabastrino, oniciata bruno, etc.

Physical-mechanical properties of three travertine varieties are given in Table 1 . For the comparison, calc-tufa properties are presented. The differences in all the properties of travertine and calc-tufa are obvious and significant.

Table 1.

Physical-mechanical properties of travertines and calc-tufa
It is interesting that various authors give very different descriptions of some travertine properties. For example some authors write about travertine as a porous stone, while others that it is compact. The fact is that travertine is vuggy and it contains easily noticeable cavities that are round (bubble-like) oval and irregular. Between these macroscopic cavities, travertine is dense.

Due to the accentuated vuggy structure, travertine is resinstant to water freezing in the cavities, and it is also not effected by elevated temperatures. Among all types of rocks that are used as dimensional stone, travertine is distinguished by smallest thermal expansion (Fig. 6, after R i c h $t 1$ i n e n fur ..., 1973). Such properties of travertine under insulation and heating is especially important in revetment of building facades,

\section{Conclusion}

The third restoration of the cathedral in Zagreb (the first was around 1938, and the second around

\begin{tabular}{|c|c|c|c|c|c|}
\hline & 1 & 2 & 3 & 4 & 5 \\
\hline compressive breaking load (MPa) & 111,3 & 92.5 & 115,3 & $12.0-16.5$ & 11,9 \\
\hline $\begin{array}{l}\text { compressive breaking load after } \\
\text { freezing (MPa) }\end{array}$ & 113,1 & 83.3 & 113.2 & - & - \\
\hline $\begin{array}{l}\text { ultimate tensile } \\
\text { strenght }(\mathrm{MPa})\end{array}$ & 14.1 & 12.7 & 14.6 & $2.5-3.2$ & 1.57 \\
\hline imbibition coefficient (by weight, \%) & 8.0 & 8.85 & 7.30 & $12.0-21.0$ & 14.2 \\
\hline impact test: min. fall height $(\mathrm{cm})$ & 30 & 36 & 29 & - & - \\
\hline $\begin{array}{l}\text { thermal linear expansion } \\
\text { coefficient }\left(\mathrm{mm} / \mathrm{m}{ }^{\circ} \mathrm{C}\right)\end{array}$ & 0.0049 & 0.0046 & 0.0060 & - & - \\
\hline $\begin{array}{l}\text { friction wear test: } \\
\text { relative abrasion } \\
\text { coefficient (ratio between abraded } \\
\text { friction wear test: } \\
\text { layers in the San Fedelino granite and }\end{array}$ & - & 0.38 & 0.72 & - & - \\
\hline weight per unit of volume $\left(\mathrm{kg} / \mathrm{m}^{3}\right)$ & 2447 & 2473 & 2437 & $1615-1820$ & 1630 \\
\hline
\end{tabular}

\footnotetext{
1 - Travertino Romano chiaro, Tivoli, Italy

2 - Travertino Romano chiaro fosse, Tivoli, Italy

3 - Travertino Romano oniciato, Tivoli, Italy

4 - Calc - tufa, Plivit Jajce, Bosnia and Herzegovina - Calc-tufa, Lehnjak Jezersko, Slovenia
}

The chemical composition of travertine (variety Travertino Romano chiaro) is given in Table 2.

\section{Table 2}

Chemical composition of travertine

(Travertino Romano chiaro)

\begin{tabular}{lr}
$\mathrm{SiO}_{2}$ & $0.68 \quad(\%)$ \\
$\mathrm{Al}_{2} \mathrm{O}_{3}$ & 0.54 \\
$\mathrm{Fe}_{2} \mathrm{O}_{3}$ & 0.06 \\
$\mathrm{CaO}$ & 54.77 \\
$\mathrm{MgO}$ & 0.18 \\
$\mathrm{CO}_{2}$ & 43.01 \\
$\mathrm{SO}_{4}$ & 0.45 \\
$\mathrm{P}_{2} \mathrm{O}_{5}$ & 0.01 \\
\hline
\end{tabular}

1968) began with complete replacement of the first gallery stone (the first and the second console cornices, balustrade and pinnacles). The restoration work on the gallery was finished in 1994, and was followed by the restoration of the tympanum. The original stone, lithotamnian limestone, from the SW slopes of Mt. Medvednica near Zagreb, is being replaced with travertine, San Pietro classico variety from a deposit in the Acque Albule basin near Rome. Travertino romano San Pietro classico was chosen primarily because of the following two reasons: 


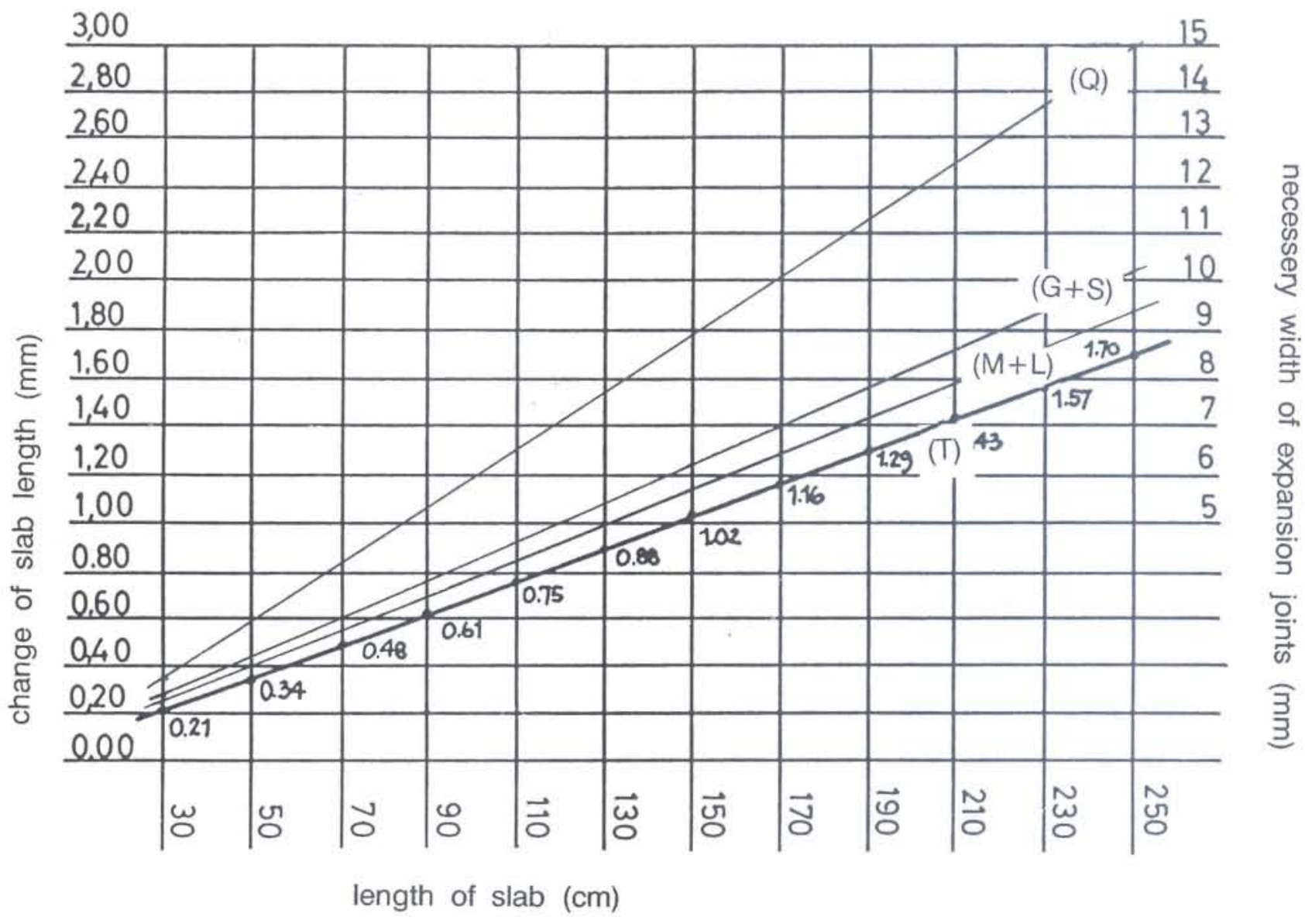

Fig. 6. Thermal linear expansion of travertine slabs by $100^{\circ} \mathrm{C}$ of yearly temperature differenze, after

DIN 18515 (from Richtlinien fur ..., 1973)

(Q) Quartz sandstones (thermal linear coefficient $=1.20 \mathrm{~mm} / \mathrm{m}^{\circ} \mathrm{C}$ )

$(\mathrm{G}+\mathrm{S}) \quad$ Granites and sienites (thermal linear coefficient $=0.80 \mathrm{~mm} / \mathrm{m}^{\circ} \mathrm{C}$ )

$(\mathrm{M}+\mathrm{L})$ Marbles and dense limestones (thermal linear coefficient $=0.75 \mathrm{~mm} / \mathrm{m}^{\circ} \mathrm{C}$ )

(T) Travertines (thermal linear coefficient $=0.68 \mathrm{~mm} / \mathrm{m}^{\circ} \mathrm{C}$ )

1. Because of the visual similarity with lithotamnian limestone; it is yellow-whitish to yellow-grayish in color and porous, regardless of the fact that in travertine, the cavities are subparalelly arranged in space, and in lithotamnian limestone they are not,
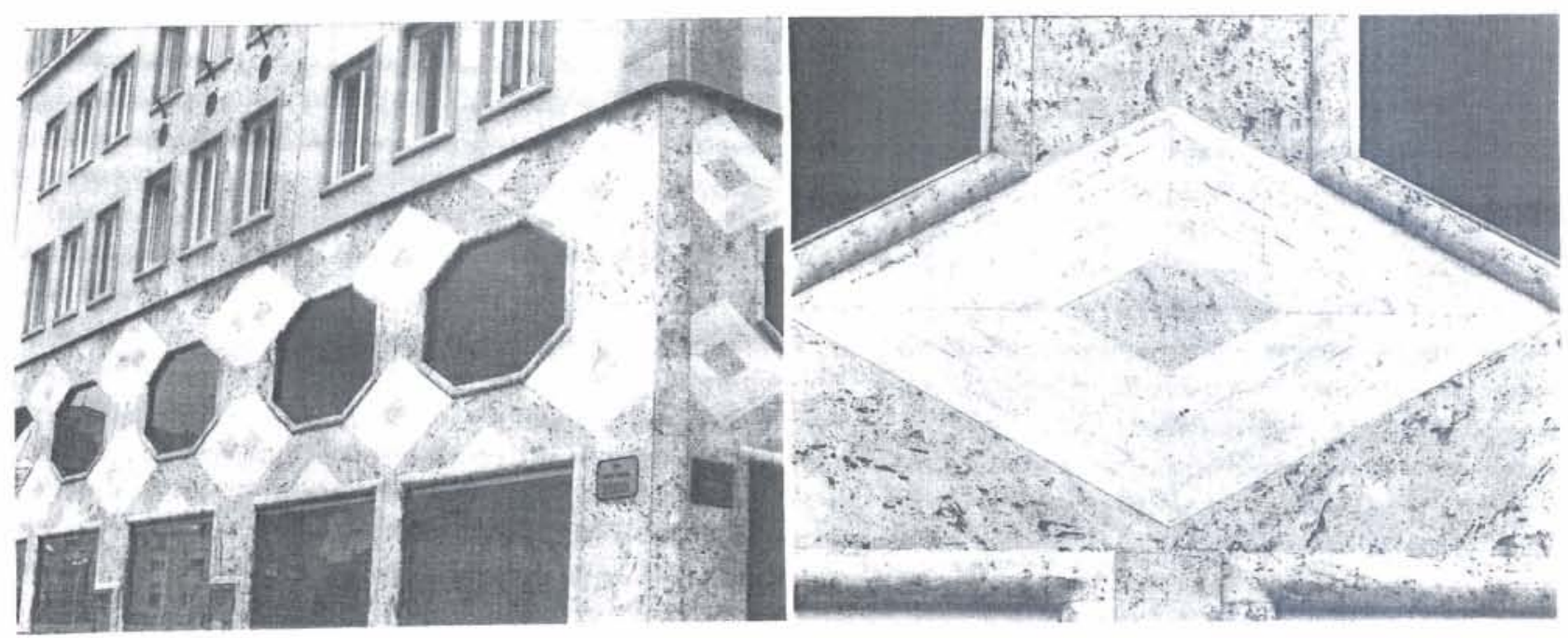

Fig. 7.Front of Dubrovnik Hotel, Trg bana Josipa Jelačica in Zagreb, coated by slabs of travertine (banded structure), and calc-tufa (sponge-like appearance) (Photo: D. Jovičić) 
except in rare cases when in some parts lithotamnian limestone is particularly stratified;

2. Travertine has specially favorable physical-mechanical properties, better than lithotamnian limestone, and is durable in the urban environment.

Lithotamnian limestone, especially so called "litavac" type, has been, during history, used as construction stone in many buildings. It was the construction stone of the city of Zagreb. A large part of lithotamnian limestone used as dimension stone was weathered and destroyed under the influence of natural and urban products of the urban environment and is so ruinous and weathered that a restoration of many buildings is needed. State and regional institutions that take care of the material legacy of the cultural heritage were advised to replace lithotamnian limestone in the all buildings in Zagreb with roman travertine. Because of this, it is useful to acquaint all interested institutions and persons with the deposit of travertine from the Acque Albule basin and its characteristics.

At the same time, we consider it inevitable to point out the need to reject the equalization of travertine and calc-tufa. Although travertine and calc-tufa, are formed by precipitation of calcite from water saturated with calcium hydrocarbonate, they differ in their genesis, because travertine is formed from the warm waters of juvenile origin or mineralized deep waters, and calc-tufa is formed from cold waters in karst regions. This genetic difference is manifested in their structure and in large differences in their physical-mechanical properties (see Table 1). The most obvious example of the difference in their structure and appearance can be seen when they are used as building stone alongside, for instance on the facade of Hotel Dubrovnik in Zagreb, Trg Bana Jelačića (Fig. 7.). We think that the enclosed photography does not need any comment.

Finally, travertine is a dimensional stone of world-wide significance, while calc-tufa is a dimensional stone of local, at best regional importance.

Received: 15.II.1995.

Accepted: 20.VI.1995.

\section{REFERENCES}

Alla by, A \& All a by, M. (1990): The Concise Oxf ord Dictionary of Earth Sciences. Oxford University Press, 410 pp. Oxford, New York.

Arnórsson, S. (1990): Gas Chemistry of Geothermal Systems, In: Geochemistry of Gaseous Elements and Compounds. Theophrastus Publ. S. A. 187-222, Athens.

B a te s, R. L. \& J a c k s o n, J. A. (1980): Glossary of Geology. American Geological Institute, 751 pp. Falls Church, Virginia.

C h a f e t z, H. S. \& F o I k, P. L. (1984): Travertines: Depositional morphology and the bacterially constructed constituents. $J$. Sedim. Petrol. 54(1), 289-316.

C h a f e t z, H. S., Rush, P. F. and Utech, N. M. (1991): Microenvironmental controls on mineralogy and habit of $\mathrm{CaCO}_{3}$ precipitates: an example from an active travertine system. Sedimentology 38, 107-126.

Cortesi, C. \& Le o n i, M. (1958): Studio sedimentologico e geochimico del travertino di un sondaggio a Bagni di Tivoli. Periodico di Mineralogia 27, 407-458

Crnkovic, B., T a de j, N. and P oll a k, D. (1994): The influence of acid rains on the lithothamnian limestone on the gallery of the Mary's ascension cathedral, Zagreb. Croatia. Rud.-geol.-naft. zb. 6, 1-9, Zagreb.

Em e is, K. C., R i ch n ow, H. H. and Ke m p l, S. (1987): Travertine formation in Plitvice National Park, Yugoslavia: Chemical versus biological control. Sedimentology 34, 595-609.

F I ü g e 1, E. (1982): Microfacies Analysis of Limestones. Springer-Verlag, 633 pp., Berlin-Heidelberg-New York.

K r a u s k o p f, K.B. (1982): Introduction to Geochemistry. Sec. Ed. Mc Graw-Hill Book Co. 616 pp. Singapore.

Mat on ičkin, I. P avle t ić, Z., Tavčar, V. i Krkač, N. (1971): Limnološka istraživanja reikotopa i fenomen protočne travertinizacije u Plitvičkim jezerima (The limnological investigations of reicotops and phenomenon of current travertinisation in Plitvice Lakes). Acta Biologica 7/1, 1-68, Zagreb.

M a x i a, C. (1950a): Un interessante sondaggio nel travertino di Bagni di Tivoli (Acque Albule, fra Tivoli e Roma). Contributi di Scienze Geologiche, "Supp. La Ricerca Scientifica" 20/22, 3-8, Roma.

M a x i a, C. (1950b): Il Bacino delle Acque Albule (Lazio). Contributi di Scienze Geologiche, "Supp. La Ricerca Scientifica 20/27, 3-20, Roma.

Me h l i n g, G. (1986): Naturstein-lexikon (Werkstoff, Werkzeuge und Maschinen, Wirtschaft und Handel, Gestaltung und Techniken von der Antike bis Heute). Verlag Georg D.W. Callwey, 655 pp. Munchen.

P i e r i, M. (1950): I Marmi d'Italia - Granite e Pietre ornamentali. Ed. Ulrico Hoepli, 427 pp., 32 tab., Milano

T i š l j a r, J. (1994): Sedimentne stijene (Sedimentary Rocks) Školska knjiga, 422 pp. Zagreb.

To m k e i e f f, S.J. (1983): Dictionary of Petrology. John Wiley \& Sons, 680 pp. New York, Toronto, Singapore.

W a g n e r, M.E. (1994): Travertine. In: 9 The World Book Encyclopedia, Vol. 19, 406 p. World Book, Inc. Chicago.

.... (1973): R i c h t l i n i e n für das Versetzen und Verlegen von Naturwerksteinen. 7. Auflage, Deutschen Naturwerkstein Verband e.V. 83 pp. Würzburg. 